\title{
A conceptual model for measuring the competency level of Small and Medium-sized Enterprises (SMEs)
}

\author{
Oztemel, E. ${ }^{\text {a }, ~ O z e l, ~ S . ~}{ }^{\text {a, }}$ \\ ${ }^{a}$ Department of Industrial Engineering, Marmara University, Istanbul, Turkey
}

\begin{abstract}
A B S T R A C T
Small and Medium-Sized Enterprises (SMEs) are of major importance to developing countries. SMEs are the main drivers to strengthen society in sustaining economic growth and development. Governments provide various support programs to improve their industrial power and to increase the number of enterprises in the market. The enterprises must be assessed and suitable funds should be provided to those in need, to achieve an effective support program in the most efficient way.This requires implementing an assessment methodology based on a predefined set of scientific criteria. The current literature is comprehensive enough to assess the healthiness of the enterprises concerning strategic, technologic, financial as well as intellectual competencies but on the other hand, it lacks of an assessment model. This study aims to introduce a general framework for sustaining an effective assessment methodology for SMEs to eliminate this gap. The proposed model measures five different types of competencies such as Technological Competency, Strategic Competency, Financial Competency, Intellectual Competency, R\&D and Innovation Competency. These competencies are to put forth the conditions in which the enterprises are running accurately. A real-life case study is conducted to ensure the baseline of the model to be implemented. The governmental organizations may utilize the model for sustaining their support role effectively to SMEs.
\end{abstract}

\section{ARTICLE INFO}

Keywords:

Small and medium-sized enterprises (SMEs);

Competency assessment; Technological competency; Strategic competency; Financial competency; Intellectual competency; R\&D and innovation competency; Smart manufacturing; Industry 4.0

*Corresponding author: semih.ozel@marmara.edu.tr (Ozel, S.)

Article history:

Received 2 January 2020

Revised 9 March 2021

Accepted 10 March 2021

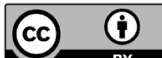

Content from this work may be used under the terms of the Creative Commons Attribution 4.0 International Licence (CC BY 4.0). Any further distribution of this work must maintain attribution to the author(s) and the title of the work, journal citation and DOI.

\section{References}

[1] Frijns, J., van Vliet, B. (1999). Small-scale industry and cleaner production strategies, World Development, Vol. 27, No. 6, 967-983, doi: 10.1016/S0305-750X(99)00044-3.

[2] Hillary, R. (2000). Small and medium-sized enterprises and the environment: Business imperatives, First edition, Greenleaf Publishing, Sheffield, United Kingdom, doi: 10.4324/9781351282840.

[3] OECD (2013). Creating Value from Intellectual Assets. OECD council meeting report, OECD publication, from https://www.oecd.org/sti/inno/36701575.pdf, accessed January 12020.

[4] OECD (2004). Small and medium-sized enterprises in Turkey: Issues and policies. Organisation for Economic CoOperation and Development Report, Paris, France, $\underline{\text { https://www.oecd.org/turkey/31932173.pdf. }}$.

[5] KOSGEB (2019). 2019-2023 Stratejik Plan, from https://www.kosgeb.gov.tr/Content/Upload/Dosya/Mevzuat L2020/KOSGEB Stratejik Plan\%C4\%B1 (2019-2023).pdf accessed March 1, 2021.

[6] Mell, P., Grance, T. (2011). The NIST definition of cloud computing, U.S. Department of Commerce National Institute of Standards and Technology (NIST), NIST Special Publication of Cloud Computing, 800-145, doi: 10.6028/NIST.SP.800-145.

[7] Dragic, M., Sorak, M. (2016). Simulation for improving the performance of small and medium-sized enterprises, International Journal of Simulation Modelling, Vol. 15, No. 4, 597-610, doi: 10.2507/IJSIMM15(4)2.343. 
[8] Emebo, O., Daramola, O., Ayo, C. (2017). A survey on implicit requirements management practices in small and medium-sized enterprises, Tehnički Vjesnik - Technical Gazette, Vol. 24, Supplement 1, 219-227, doi: 10.17559/ TV-20150823114946.

[9] Sohn, S.Y., Kim, H.S., Moon, T.H. (2007). Predicting the financial performance index of technology fund for SME using structural equation model, Expert Systems with Applications, Vol. 32, No. 3, 890-898, doi: 10.1016/ j.eswa.2006.01.036.

[10] Chen, X.-H., Li, J.-M., Wang, X.-D. (2008). Governance of creditor's rights evaluation and growth of SMEs: An empirical study based on Chinese listed SMEs", In: Proceedings of $4^{\text {th }}$ International Conference on Wireless Communications, Networking and Mobile Computing, WICOM'08, Dalian, China, 8474.

[11] Moon, T.H., Sohn, S.Y. (2005). Intelligent approach for effective management of government funds for small and medium enterprises, Expert Systems with Applications, Vol. 29, No. 3, 566-572, doi: 10.1016/j.eswa.2005.04.019.

[12] Yang, J.-C. (2006). The efficiency of SMEs in the global market: Measuring the Korean performance, Journal of Policy Modeling, Vol. 28, No. 8, 861-876, doi: 10.1016/i.jpolmod.2006.07.004.

[13] Sohn, S.Y., Kim, H.S. (2007). Random effects logistic regression model for default prediction of technology credit guarantee fund, European Journal of Operational Research, Vol. 183, No. 1, 472-478, doi: 10.1016/i.ejor.2006. $\underline{10.006}$.

[14] Ying, Y., Li, J.-C. (2009). A fuzzy-AHP based innovation ability evaluation system for small and medium-sized enterprise clusters, In: Proceedings of 2009 International Conference on Information Management, Innovation Management and Industrial Engineering, Xi'an, China, 277-281, doi: 10.1109/ICIII.2009.74.

[15] Kaufmann, A., Tödtling, F. (2002). How effective is innovation support for SMEs? An analysis of the region of Upper Austria, Technovation, Vol. 22, No. 3, 147-159, doi: 10.1016/S0166-4972(00)00081-X.

[16] Cheng, Q., Wang, M. (2009). Risk analysis and evaluation of the destructive innovation in small and mediumsized enterprises, In: Proceedings of 2009 International Conference on Management and Service Science, Beijing, China, 2009, 1-5, doi: 10.1109/ICMSS.2009.5305759.

[17] Wang, Z. (2008). Comparative research on the evaluation method of external environment of small and mediumsized enterprises, In: Proceedings of $4^{\text {th }}$ International Conference on Wireless Communications, Networking, and Mobile Computing, WICOM'08, Dalian, China, 1-4, doi: 10.1109/WiCom.2008.1969.

[18] Hvolby, H.H., Thorstenson, A. (2001). Indicators for performance measurement in small and medium-sized enterprises, Proceedings of the Institution of Mechanical Engineers, Part B: Journal of Engineering Manufacture, Vol. 215, No. 8, 1143-1146, doi: 10.1243/0954405011518926.

[19] Barnes, M., Dickinson, T., Coulton, L., Dransfield, S., Field, J., Fisher, N., Saunders, I., Shaw, D. (1998). A new approach to performance measurement for small to medium enterprises, In: Proceedings of the Performance Measurement - Theory and Practice Conference, Cambridge, United Kingdom.

[20] Hudson, M., Smart, A., Bourne, M. (2001). Theory and practice in SME performance measurement systems, International Journal of Operations \& Production Management, Vol. 21, No. 8, 1096-1115, doi: 10.1108/EUM 0000000005587.

[21] Delisle, S., Dugré, M., St-Pierre, J. (2004). Performance evaluation: Upgrading to data warehousing \& data mining techniques, In: Proceedings of the International Conference on Information and Knowledge Engineering, Las Vegas, USA.

[22] Brem, A., Kreusel, N., Neusser, C. (2008). Performance measurement in SMEs: Literature review and results from a German case study, International Journal of Globalisation and Small Business, Vol. 2, No. 4, 411-427, doi: 10.1504/IJGSB.2008.018102.

[23] Hanif, A., Manarvi, I.A. (2009). Performance-based segmentation of small and medium enterprises: A data mining approach, In: Proceedings of 2009 International Conference on Computers \& Industrial Engineering, Troyes, France, 1509-1513, doi: 10.1109/ICCIE.2009.5223690.

[24] Kim, K.S., Knotts, T.L., Jones, S.C. (2008). Characterizing viability of small manufacturing enterprises (SME) in the market, Expert Systems with Applications, Vol. 34, No. 1, 128-134, doi: 10.1016/j.eswa.2006.08.009.

[25] Abouzeedan, A., Busler, M. (2004). Typology analysis of performance models of small and medium-size enterprises (SMEs), Journal of International Entrepreneurship, Vol. 2, 155-177, doi: 10.1023/B:JIEN.0000026911. 03396.2d.

[26] Ozturk, E., Coskun, A. (2014). A strategic approach to performance management in banks: The balanced scorecard, Accounting and Finance Research, Vol. 3, No. 3, 151-158, doi: 10.5430/afr.v3n3p151.

[27] Lin, L.C., Tong, L.I. (2010). Constructing two-stage credit scoring model using Cox model and SVM: The case of SMEs in Taiwan, The Journal of American Academy of Business, Vol. 15, No. 2, 300-306.

[28] Katwalo, A.M. (2006). An overview of competence development in SMEs, International Journal of Strategic Change Management, Vol. 1, No. 1-2, 89-95, doi: 10.1504/IJSCM.2006.011104.

[29] Cassell, C., Nadin, S., Older Gray, M. (2001). The use and effectiveness of benchmarking in SMEs, Benchmarking: An International Journal, Vol. 8, No. 3, 212-222, doi: 10.1108/EUM0000000005624.

[30] Vanhoof, K., Houben, G., Lenie, K. (1995). A qualitative analysis of small and medium-sized enterprises, In: Proceedings of the $11^{\text {th }}$ Conference on Artificial Intelligence for Applications, Los Angeles, USA, 286-291.

[31] Fernandes, K.J., Raja, V., Whalley, A. (2006). Lessons from implementing the balanced scorecard in a small and medium size manufacturing organization, Technovation, Vol. 26, No. 5-6, 623-634, doi: 10.1016/j.technovation. 2005.03.006.

[32] Romano, C.A., Tanewski, G.A., Smyrnios, K.X. (2000). Capital structure decision making: A model for family business, Journal of Business Venturing, Vol. 16, No. 3, 285-310, doi: 10.1016/S0883-9026(99)00053-1.

[33] Collin, A. (1989). Managers' competence: Rhetoric, reality, and research, Personnel Review, Vol. 18, No. 6, 20-25, doi: $10.1108 / 00483488910133459$. 
[34] Hitt, M.A., Ireland, R.D., Hoskisson, R.E. (2015). Strategic management: Competitiveness and globalization, 11 th edition, Cengage Learning, Cincinnati, USA.

[35] Keršulienè, V., Turskis, Z. (2011). Integrated fuzzy multiple criteria decision-making model for architect selection, Technological and Economic Development of Economy, Vol. 17, No. 4, 645-666, doi: 10.3846/20294913. 2011.635718.

[36] Hashemkhani Zolfani, S., Kazimieras Zavadskas, E., Turskis, Z. (2013). Design of products with both international and local perspectives based on yin-yang balance theory and SWARA method, Economic Research - Ekonomska Istraživanja, Vol. 26, No. 2, 153-166, doi: 10.1080/1331677X.2013.11517613.

[37] Sarı, T., Güleș, H.K., Yiğitol, B. (2020). Awareness and readiness of Industry 4.0: The case of Turkish manufacturing industry, Advances in Production Engineering \& Management, Vol. 15, No. 1, 57-68, doi: 10.14743/ apem2020.1.349.

[38] Medic, N., Anisic, Z., Lalic, B., Marjanovic, U., Brezocnik, M. (2019). Hybrid fuzzy multi-attribute decision-making model for evaluation of advanced digital technologies in manufacturing: Industry 4.0 perspective, Advances in Production Engineering \& Management, Vol. 14, No. 4, 483-493, doi: 10.14743/apem2019.4.343.

[39] Kibritçioğlu, A. (1998). Determinants of economic growth, and the role of human capital in new growth models, The Journal of Ankara University SSF, Vol. 53, No. 1-4, 207-230, doi: 10.1501/SBFder 0000001947.

[40] Durand, T., Granstand, O., Herstatt, C., Nagel, A., Probert, D., Tomlin, B., Tschirky, H. (2004). Bringing technology and innovation into the boardroom, Strategy, innovation and competences for business value, Palgrave Macmillan, London, United Kingdom, doi: 10.1057/9780230512771.

[41] Kropsu-Vehkapera, H., Haapasalo, H., Rusanen, J-P. (2009). Analysis of technology management functions in finnish high tech companies, The Open Management Journal, Vol. 2, 1-10, doi: 10.2174/1874948800902010001.

[42] Cetindamar, D., Phaal, R., Probert, D. (2009). Understanding technology management as a dynamic capability: A framework for technology management activities, Technovation, Vol. 29, No. 4, 237-246, doi: 10.1016/ j.technovation.2008.10.004.

[43] Tekin, M., Güleş, H.K., Öğüt, A. (2006). Değişim çağında teknoloji yönetimi, Nobel Yayın Dağıtım, Cilt No. 79, Ankara, Turkey.

[44] Altman, E.I., Saunders, A. (1998). Credit risk measurement: Developments over the last 20 years, Journal of Banking \& Finance, Vol. 21, No. 11-12, 1721-1742, doi: 10.1016/S0378-4266(97)00036-8

[45] Altman, E.I. (2013). Predicting financial distress of companies: Revisiting the Z-score and Zeta models, In: Bell, A.R., Brooks, C., Prokopczuk, M. (eds.), Handbook of research methods and applications in empirical finance, 428456.

[46] Hussain, S., Jahanzaib, M. (2018). Sustainable manufacturing - An overview and a conceptual framework for continuous transformation and competitiveness, Advances in Production Engineering \& Management, Vol. 13, No. 3, 237-253, doi: 10.14743/apem2018.3.287.

[47] Ulgen, H., Mirze, S.K. (2004). Ișletmelerde Stratejik Yonetim, Publisher: Literatur Yayinlari, Istanbul, Turkey.

[48] Drašković, Z., Ćelić, Đ., Ćosić, I., Uzelac, Z., Petrov, V. (2019). The relationship between organizational culture and performance of SME's: Empirical study from a developing country, Tehnički Vjesnik - Technical Gazette, Vol. 26, No. 6, 1620-1627, doi: 10.17559/TV-20180801135606.

[49] Chen, Y.-S., Lin, M.-J.J., Chang, C.-H. (2009). The positive effects of relationship learning and absorptive capacity on innovation performance and competitive advantage in industrial markets, Industrial Marketing Management, Vol. 38, No. 2, 152-158, doi: 10.1016/j.indmarman.2008.12.003.

[50] Ahmad, N., Qiu, R.G. (2006). Effectiveness evaluation services for small to medium-sized manufacturing enterprise, In: Proceedings of 2006 IEEE International Conference on Service Operations and Logistics, and Informatics, Shanghai, China, 1106-1112, doi: 10.1109/SOLI.2006.328905. 


\section{APEM}

Advances in Production Engineering \& Management

Letnik 16 | Številka 1 | Marec 2021 | Strani 47-66

https://doi.org/10.14743/apem2021.1.384
ISSN 1854-6250

Spletna stran: apem-journal.org Izvirni znanstveni članek

\title{
Konceptualni model za merjenje ravni usposobljenosti malih in srednje velikih podjetij (SME)
}

\author{
Oztemel, E. ${ }^{a}$, Ozel, S. ${ }^{\text {a, }}{ }^{*}$ \\ aDepartment of Industrial Engineering, Marmara University, Istanbul, Turkey
}

\section{POVZETEK}

Mala in srednje velika podjetja (SME) so velikega pomena za države v razvoju Podjetja SME so glavna gonilna sila za krepitev družbe pri ohranjanju gospodarske rasti in razvoja. Vlade zagotavljajo različne podporne programe za izboljšanje svoje industrijske moči in povečanje števila podjetij na trgu. Da bi dosegli učinkovit program podpore, je podjetja treba oceniti in tistim, ki jih potrebujejo, zagotoviti ustrezna sredstva. To zahteva izvajanje metodologije ocenjevanja, ki temelji na vnaprej določenih znanstvenih merilih. Aktualna literatura je dovolj obsežna, da lahko ocenimo uspešnost podjetij glede strateške, tehnološke, finančne in intelektualne usposobljenosti, po drugi strani pa model ocenjevanja še ne obstaja. Namen te študije je uvesti splošen okvir za ocenjevanje podjetij SME in s tem odpraviti vrzel. Predlagani model meri pet različnih vrst usposobljenosti podjetij, in sicer tehnološko, strateško, finančno in intelektualno ter usposobljenost za raziskave in razvoj ter inovacije. Kazalniki usposobljenosti pokažejo ali podjetja delujejo ustrezno. Izvedena je študija primera na realnih podatkih, ki zagotavlja izhodišče modela. Vladne organizacije lahko uporabijo model za ohranitev svoje podporne vloge za podjetja SME.

\section{PODATKI O ČLANKU}

Ključne besede:

Mala in srednje velika podjetja (SME);

Ocena usposobljenosti; Tehnološka usposobljenost; Strateška usposobljenost; Finančna usposobljenost; Intelektualna usposobljenost; Usposobljenost za raziskave in razvoj ter inovacije;

Pametna proizvodnja; Industrija 4.0

*Kontaktna oseba: semih.ozel@marmara.edu.tr (Ozel, S.)

Zgodovina članka:

Prejet 2. januarja 2020

Popravljen 9. marca 2021

Sprejet 10. marca 2021

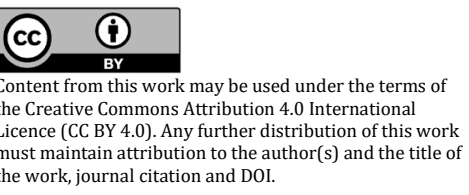

